\title{
Peningkatan pengetahuan etika beserta standar operasional prosedur dalam bisnis dan strategi pemasaran UMKM
}

\author{
Dedet Hermawan S., Abdul Haris Subarjo* \\ Jurusan Teknik Mesin, Fakultas Teknologi Kedirgantaraan \\ Institut Teknologi Dirgantara Adisutjipto \\ Email Korespondensi: *ab.haris.79@gmail.com*
}

Received July 12, 2021; Revised September 5, 2021; Accepted September 8, 2021

\begin{abstract}
Abstrak
Kegiatan Pengabdian masyarakat ini merupakan kolaborasi antara akademisi dengan pengusaha UMKM. Tujuan kegiatan adalah agar pengusaha UMKM, alumni Institut Teknologi Dirgantara Adisutjipto mendapatkan pengetahuan mengenai etika dan kode etik terutama dalam hal berbisnis. Disamping membahas tentang etika dan kode etik juga dibahas mengenai standar prosedur operasi dalam mengelola bisnis. Diharapkan dengan pembahasan standar operasi prosedur dapat meningkatkan kualitas produk UMKM yang dihasilkan dan dapat meningkatkan penjualan. Pembahasan selanjutnya adalah mengenai strategi pemasaran baik melalui membuka gerai/toko atau dengan menggunakan media sosial dan internet. Kegiatan pengabdian masyarakat ini dengan menggunakan webinar karena situasi dunia akibat bencana kesehatan covid 19. Untuk mengetahui respon peserta webinar pada akhir kegiatan diberikan pertanyaan dengan kuosioner, dari hasil kuesioner dengan pertanyaan apakah kegiatan menarik terdapat $92 \%$ peserta menjawab kegiatan menarik, $4 \%$ tidak menarik, $2 \%$ menjawab biasa dan $2 \%$ tidak menjawab. peserta kegiatan pengabdian masyarakat juga diberikan pertanyaan mengenai jawaban pemakalah atas pertanyaan dari peserta $94 \%$ menjawab bahwa pemakalah memberikan jawaban yang baik dan $6 \%$ peserta menjawab bahwa pemakalah tidak memberikan jawaban yang baik. Selain itu juga dilakukan analisis SWOT terhadap mitra kegiatan pengabdian masyarakat untuk memperoleh gambaran keunggulan, kelemahan, peluang dan tantangan mitra.
\end{abstract}

Kata Kunci: Etika dan Kode Etik; Standar Prosedur Operasi; Strategi Pemasaran; Webinar.

\begin{abstract}
This community service activity is a collaboration between academics and MSME entrepreneurs. The purpose of the activity is for MSME entrepreneurs, alumni of the Adisutjipto Aerospace Technology Institute to gain knowledge about ethics and codes of conduct, especially in terms of doing business. Besides discussing ethics and code of ethics, it also discusses standard operating procedures in managing business. It is hoped that the discussion of standard operating procedures can improve the quality of MSME products produced and can increase sales. The next discussion is about marketing strategies either through opening outlets/stores or by using social media and the internet. This community service activity uses a webinar because of the world situation due to the covid 19 health disaster. To find out the response of the webinar participants at the end of the activity, questions are asked with a questionnaire, from the results of the questionnaire with the question whether the activity is interesting there are $92 \%$ of participants answering interesting activities, $4 \%$ not interesting, $2 \%$ answered normal and $2 \%$ did not answer. participants in community service activities were also given questions about the answers of the speakers to questions from $94 \%$ of participants answered that the speakers gave good answers and 6\% of participants answered that the speakers did not give good answers. In addition, a SWOT analysis was also carried out on partners in community service activities to obtain an overview of partners' strengths, weaknesses, opportunities and challenges.
\end{abstract}

Keywords: Ethics and Code of Ethics; Standard Operating Procedures; Marketing Strategy; Webinars

\section{PENDAHULUAN}

Penyusunan (Standar Operasional Prosedur) SOP adalah salah satu hal yang penting untuk menjaga kualitas dan konsistensi produk. SOP adalah tata cara atau tahapan yang dibakukan dan harus dilalui untuk menyelesaikan suatu proses kerja tertentu.[1] dengan adanya SOP kualitas produk dan jasa yang dihasilkan akan terjaga dan konsisten hasilnya. Untuk melaksanakan kegiatan produksi selain diperlukan adanya SOP juga diperlukan adanya kode etik bagi personil yang melaksanakan kegiatan berdasarkan SOP yang telah disusun dan dibakukan. Kode etik merupakan prinsip moral dan melekat pada profesi disusun secara sistematis. apabila, tanpa kode etik disusun secara sistematis itupun suatu profesi masih tetap dapat berjalan, karena prinsip-prinsip moral tersebut sebenarnya sudah ada pada profesi tersebut. Meskipun demikian, kode etik diperlukan karena 
jumlah penyandang profesi tersebut sudah banyak, selain itu juga tuntutan masyarakat yang makin bertambah komplek dan berkembang. Pada situasi seperti inilah organisasi profesi diperlukan untuk dibentuk beserta kode etik profesi. [2] Terdapat lima indikator bila lapangan kerja dikategorikan sebagai suatu Profesi menurut Tedjosaputro dalam Kenedi (2016): Diperlukan adanya pengetahuan, Merupakan penerapan keahlian (competence of application), memiliki fungsi tanggung jawab bagi sosial (social responsibility), adanya self control, Adanya pengakuan masyarakat pada profesi[3].

Terdapat aspek-aspek berkaitan dengan etika, namun yang menjadi sorotan etika dan moral berkaitan dengan perilaku serta perbuatan pada bidang keahlian profesi. Profesi membutuhkan suatu keahlian teori dan teknis, dan bersandar pada adanya kejujuran, sehingga profesi dituntut memiliki persyaratan tertentu dalam melaksanakan tugas serta fungsi keprofesiannya, beberapa profesi diberi kewenangan dan berdasarkan undang - undang. Sehingga dalam pelaksanaan profesi diperlukan tanggung jawab secara hukum serta moral. Dengan adanya standar profesi berdasar undang-undang maka untuk menjalankan tugas profesinya dibutuhkan praktisi dengan memiliki standar kualifikasi sikap, mampu melihat dan menempatkan nilai obyektif dalam bertugas, jujur, serta memiliki kecakapan teknis dan kematangan etis[4]

Profesi memiliki arti baku, suatu pekerjaan dengan ciri suatu pengakuan umum berkaitan keahlian, keilmuan, serta kepakaran dan menyangkut pelayanan kepentingan orang lain. Dalam menentukan seorang ahli atau tidak harus ada yang menyatakan seseorang itu berhak dikatakan "ahli" dengan kata lain yang berhak menyatakan adalah 'kelompok' yang memiliki keahlian dibidang yang sama dan kelompok tersebut merupakan embrio kelahiran 'organisasi profesi'. Organisasi kemudian menetapkan kriteria dan persyaratan untuk dapat menyatakan seseorang tersebut ahli dan dapat menjadi anggota dari kelompoknya[5].

Pada kegiatan pengabdian masyarakat ini digunakan analisis SWOT (strengths, weaknesses, opportunities, threats). Digunakannya analisis SWOT hal ini untuk menganalisa perlunya kegiatan pengabdian masyarakat kolaborasi antara dosen dengan pengusaha. Analisis SWOT digunakan untuk mengidentifikasi kekurangan dan potensi mitra, sehingga kegiatan pengabdian sesuai harapan, dan bermanfaat bagi mitra dan audience. Biasanya analisis SWOT digunakan untuk mengevaluasi kekuatan, kelemahan, peluang, dan ancaman dalam suatu kegiatan bisnis[6].

Dengan adanya kegiatan pengabdian masyarakat ini diharapkan dapat menambah wawasan mitra kegiatan dan dapat memperbaiki proses bisnis yang dilakukan oleh mitra sehingga dapat meningkatkan penghasilan mitra dan tujuan akhirnya meningkatkan ketahanan ekonomi keluarga mitra. Mitra pengabdian masyarakat ini merupakan Ketahanan keluarga dapat menentukan tercapainya ketahanan daerah atau wilayah, dengan ketahanan daerah makaa akan menentukan tercapainya ketahanan nasional. ketahanan ekonomi keluarga merupakan bagian dari ketahanan keluarga. Untuk meningkatkan Ketahanan Ekonomi Keluarga dengan cara meningkatkan keterampilan[7].

Kegiatan ini selain diikuti oleh UMKM juga diikuti oleh alumni Teknik Mesin Institut Teknologi Dirgantara Adisutjipto (ITDA), dengan mengikuti kegiatan ini diharapkan para alumni dapat memperoleh pengetahuan untuk merencanakan kegiatan bisnis dibidang teknik mesin dan memiliki pengetahuan tentang penerapan metode SWOT dan mengetahui pentingnya pelaksanaan setiap kegiatan organisasi berpedoman dengan SOP secara konsisten.

\section{METODE}

Metode kegiatan pengabdian masyarakat kolaborasi dosen ITDA dengan pengusaha UMKM ini merupakan pelatihan dan diskusi dengan tujuan untuk memperbaiki proses bisnis anggota UMKM serta menambah wawasan bagi masyarakan yang akan memulai kegiatan bisnis. Materi Presentasi berasal dari Dosen dan pengusaha UMKM yang menyampaikan materi secara teoritis dan pengalaman yang dari pemakalah. Presentasi pada kegiatan ini dilakukan dengan menggunakan webinar. Hal ini karena situasi Indonesia dan dunia yang sedang mengalami bencana internasional mewabahnya virus corona. Kegiatan pengabdian dilaksanakan selama satu hari dengan peserta dari UMKM serta masyarakat umum. Jumlah calon peserta yang mendaftar cukup banyak sekitar 257 peserta. Setelah dilakukan presentasi, kegiatan selanjutnya dilakukan dengan metode tanya jawab. Metode tanya jawab dapat bermanfaat untuk melatih peserta dalam mengemukan pendapat pada saat berdiskusi sehingga menciptakan kegiatan pelatihan menjadi lebih menyenangkan. Tanya jawab memiliki dampak pada peningkatan motivasi para peserta. [8]

Untuk menganalisis kondisi mitra digunakan analisis SWOT (strengths, weaknesses, opportunities, threats). Analisis SWOT merupakan penilaian terhadap hasil identifikasi terhadap situasi, untuk menentukan suatu kondisi dapat dikategorikan sebagai kekuatan, kelemahan, peluang atau ancaman. Analisis SWOT merupakan bagian proses perencanaan. Proses perencanaan tersebut, suatu organisasi membutuhkan penilaian tentang kondisi saat ini dan gambaran situasi kedepan yang mempengaruhi proses dari pencapaian tujuan organisasi. Dengan menggunakan analisa SWOT akan diperoleh karakteristik dari kekuatan utama, kekuatan pendukung, faktor netral, kelemahan utama dan kelemahan lain berdasarkan analisa dari lingkungan internal dan eksternal yang dilakukan. [9] 


\section{HASIL DAN PEMBAHASAN}

Kegiatan pengabdian masyarakat yang dilaksanakan oleh dosen teknik mesin Institut Teknologi Dirgantara Adisutjipto (dahulu bernama Sekolah Tinggi Teknologi Adisutjipto atau disingkat STTA) merupakan kolaborasi dengan pengusaha usaha mikro kecil dan menengah (UMKM) di Propinsi Daerah Istimewa Yogyakarta, personil yang terlibat diantara Dedet Hermawan S. (Waket I), Abdul Haris S. (dosen ITDA), Dwi Karti Handayani dan Sofyani Mirah selaku pengusaha UMKM dengan moderator Maria Asumpta (dosen ITDA) dan tim IT Wita Setianingsih (dosen UNY).

Kegiatan pengabdian masyarakat ini dilaksanakan dengan metode webinar, hal ini karena ancaman bencana kesehatan corona virus 19 yang tidak hanya dialami oleh Indonesia namun juga Negara lain, sehingga untuk meminimalkan resiko maka kegiatan pengabdian masyarakat dilaksanakan dengan webinar. Kegiatan masyarakat ini diikuti oleh 257 peserta yang berasal dari berbagai daerah di Indonesia.

Karena adanya bencana kesehatan Covid 19 maka kegiatan yang berhubungan dengan pendidikan juga dianjurkan menggunakan metode daring seperti yang dilakukan oleh tim pengabdian masyarakat dari Universitas Budi Luhur yang mengadakan pelatihan untuk Pusat Kegiatan Belajar Masyarakat (PKBM) Bhakti Asih, Ciledug dengan media Zoom Cloud Meeting.[10]

Pada kegiatan pengabdian masyarakat ini narasumber mempresentasikan makalah yang telah dipersiapkan. Pada presentasi ini narasumber tidak hanya menyampaikan tentang teoritis namun juga membagikan pengalaman yang telah mereka miliki, setelah presentasi oleh narasumber dilanjutkan dengan kegiatan tanya jawab oleh peserta kegiatan. Pada akhir kegiatan masing-masing narasumber memberikan pertanyaan kepada peserta, hal ini untuk melihat bahwa peserta memiliki nilai tambah setelah mengikuti kegiatan.

Antusias peserta cukup baik terlihat dari pertanyaan yang diajukan oleh peserta kepada narasumber serta antusiasme peserta kegiatan dalam menjawab pertanyaan yang diajukan oleh narasumber. Antusiasme juga terlihat dari jumlah peserta yang tidak berkurang dari awal sampai akhir kegiatan. Pada saat kegiatan cuaca sedang tidak bersahabat karena sedang hujan lebat sehingga berpengaruh pada pemakalah dan peserta yang kesulitan untuk masuk ke jaringan zoom. Pada saat presentasi pemateri Dedet Hermawan S., S.T., M.T. menemui kendala yaitu file presentasi yang telah dipersiapkan tidak bisa dibuka sehingga presentasi ditunda dan diganti oleh presenter berikutnya dan pemateri Dedet Hermawan S., S.T., M.T kembali mempresentasikan makalahnya setelah diperbaiki.

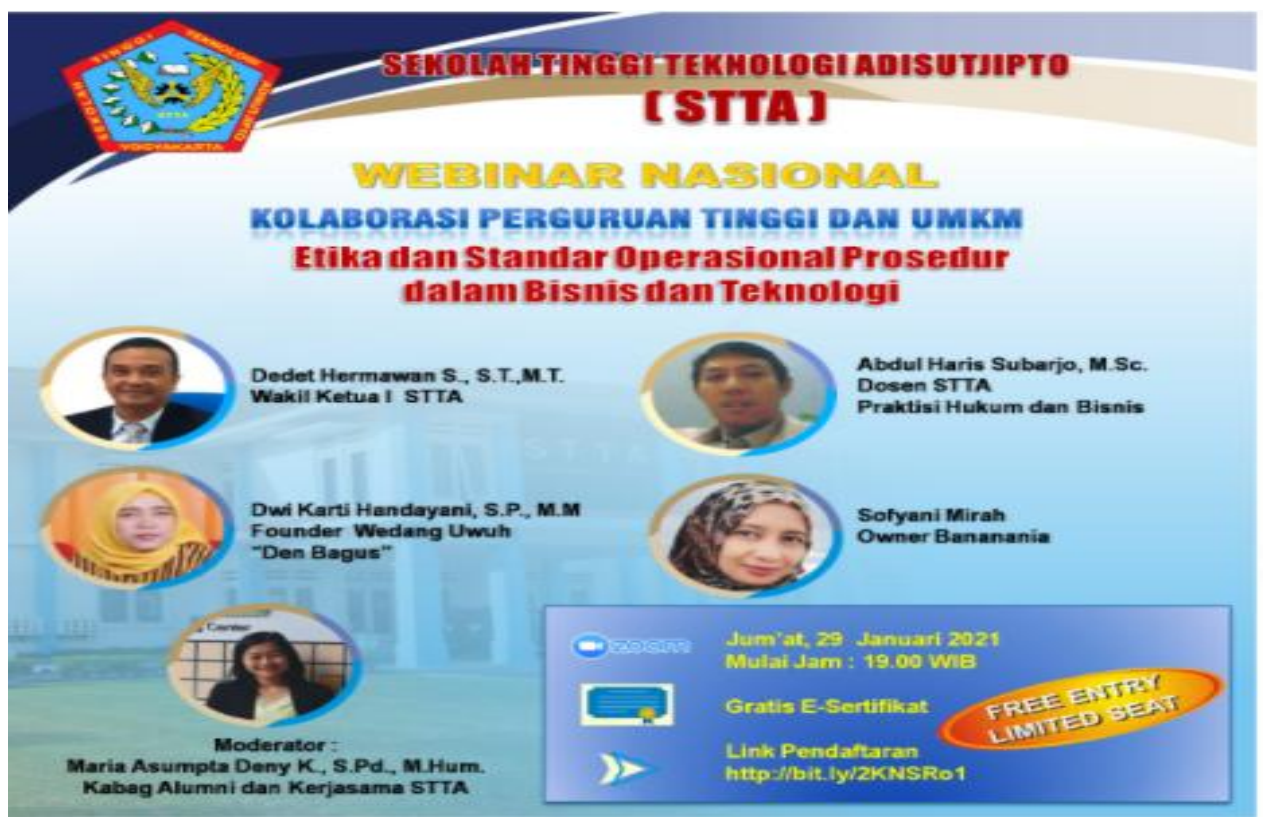

Gambar 1. Flayer sosialisasi kegiatan pengabdian masyarakat 


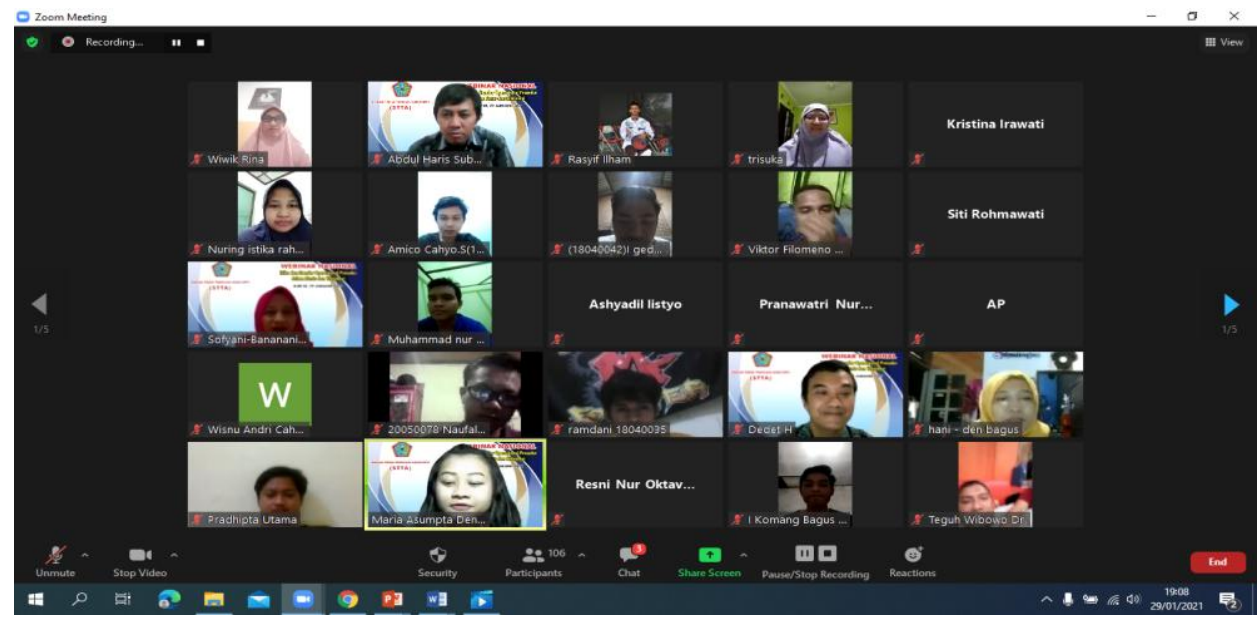

Gambar 2 Gambar Print Screen layar 1 peserta webinar

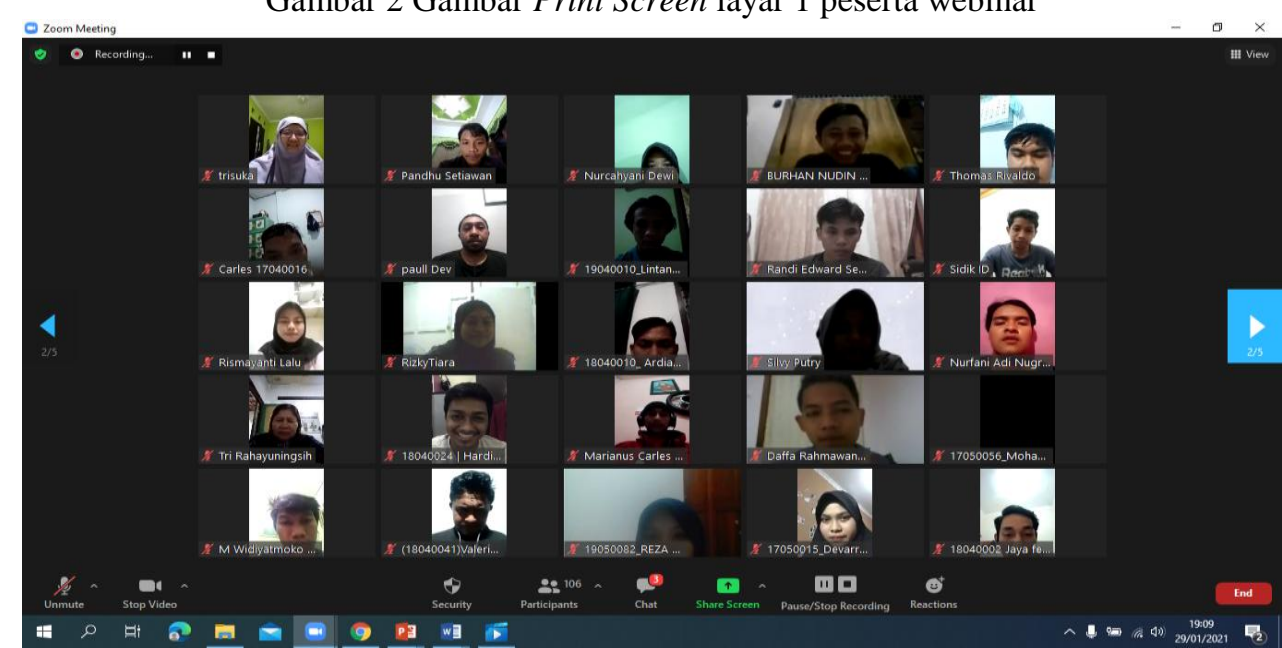

Gambar 3 Gambar Print Screen layar 2 peserta webinar

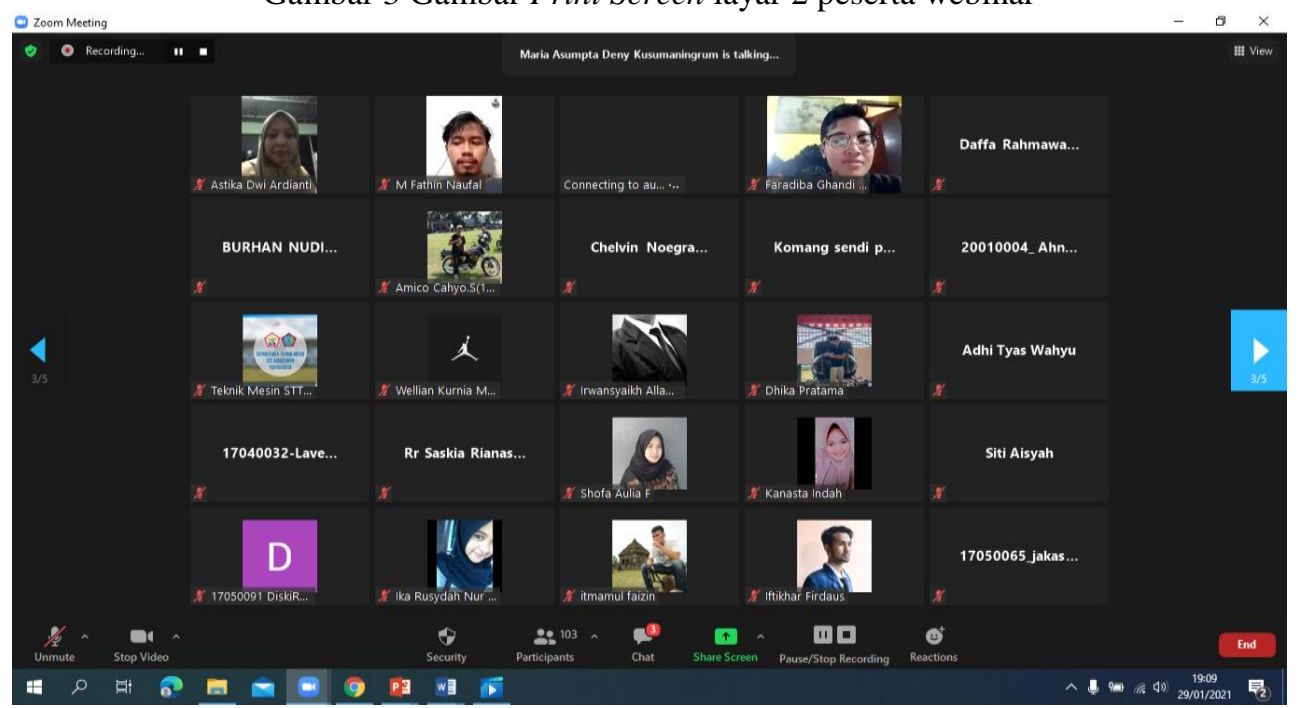

Gambar 4 Gambar Print Screen layar 3 peserta webinar 


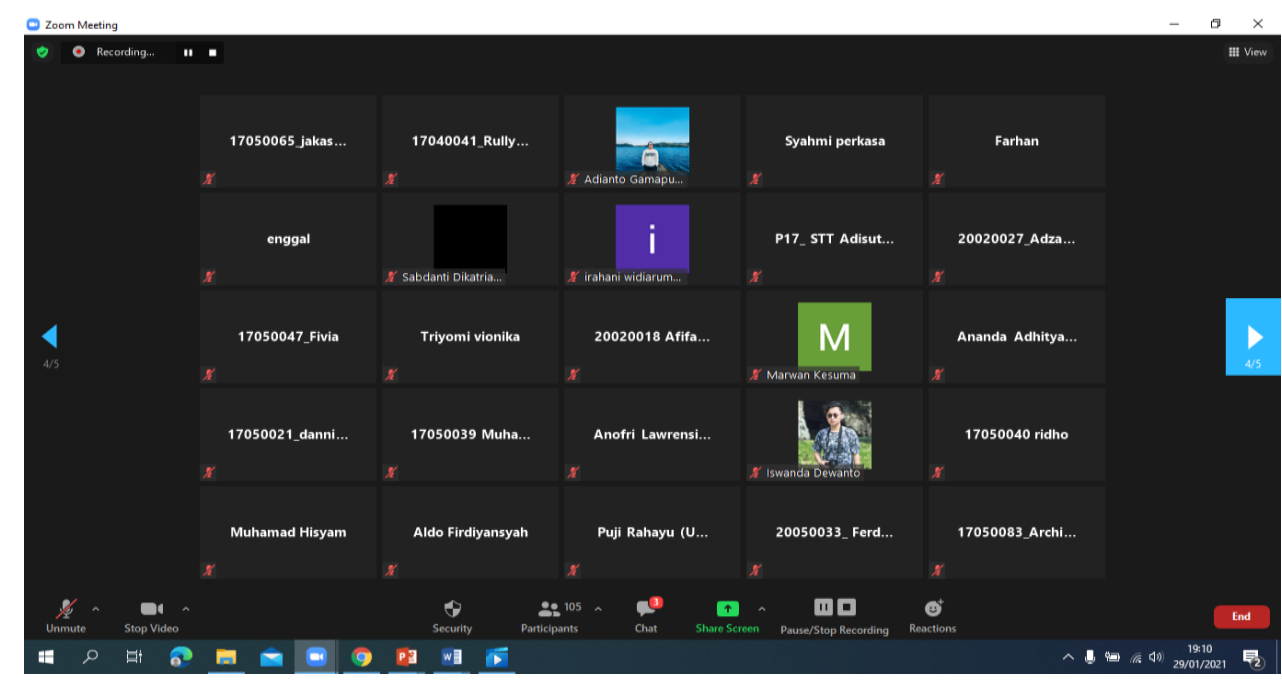

Gambar 5 Gambar Print Screen layar 4 peserta webinar
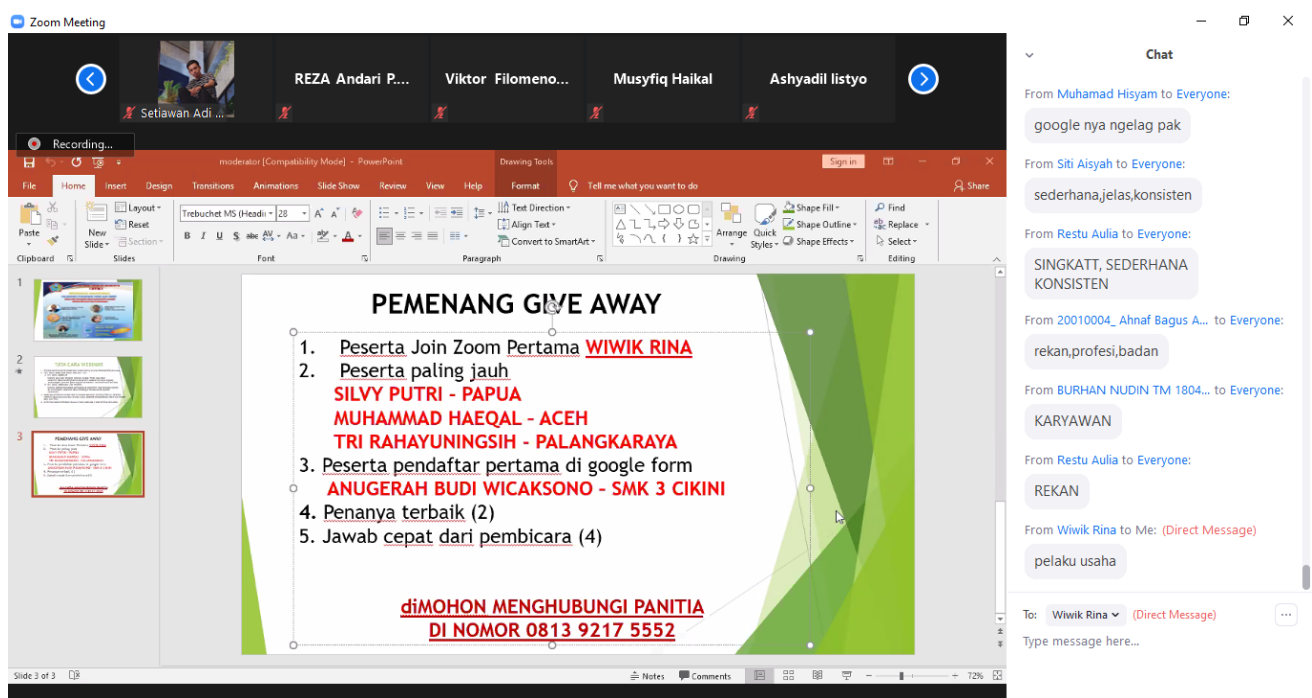

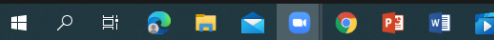

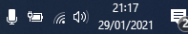

Gambar 6 Gambar Print Screen pemenang give away

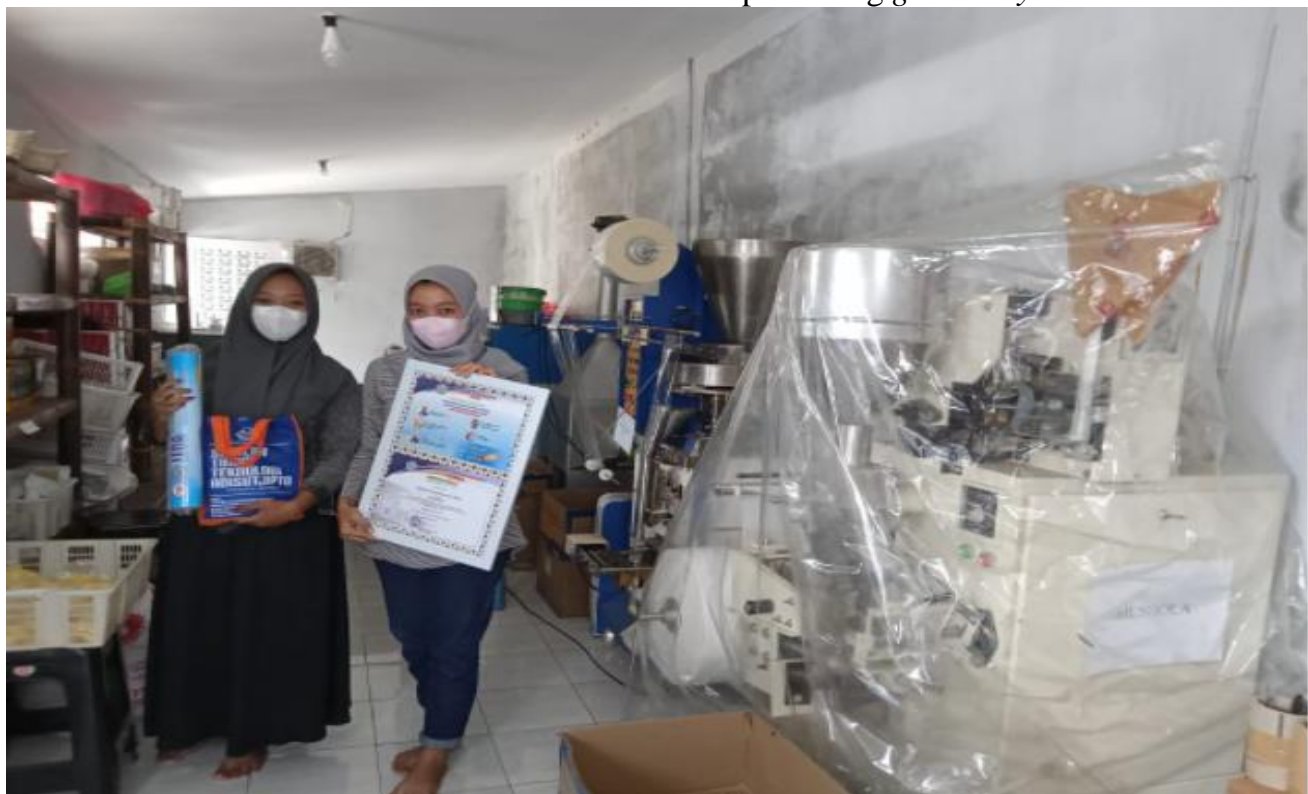

Gambar 7 Penyerahan cidera mata kepada mitra yang menjadi pembicara 


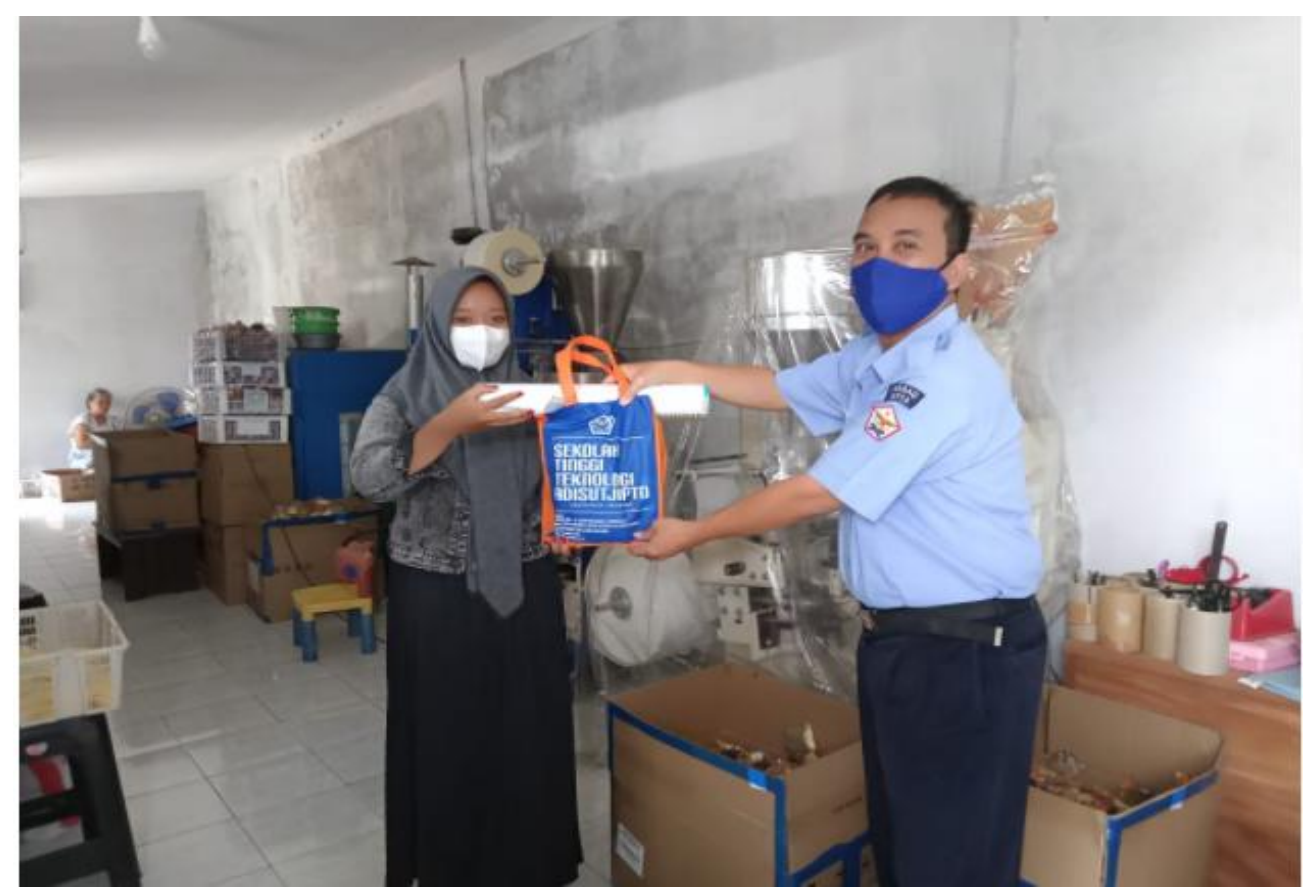

Gambar 8 Penyerahan cidera mata kepada mitra pengabdian yang menjadi salah satu pembicara

Pada akhir kegiatan dilakukan pengisian kuesioner mengenai jalannya kegiatan pengabdian masyarakat, dari hasil kuesioner dengan pertanyaan apakah kegiatan menarik terdapat $92 \%$ peserta menjawab kegiatan menarik, $4 \%$ tidak menarik, $2 \%$ menjawab biasa dan $2 \%$ tidak menjawab, untuk lebih jelas dapat dilihat pada gambar 9.

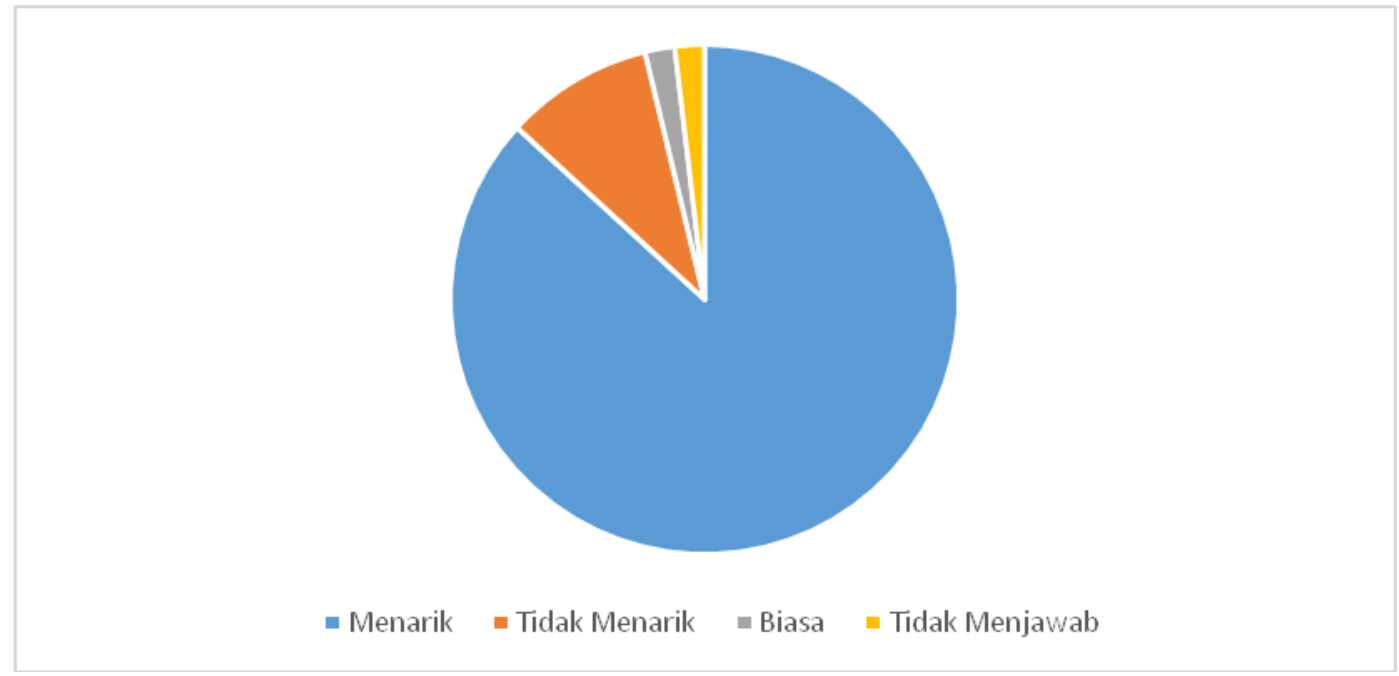

Gambar 9. Grafik respon peserta kegiatan pengabdian masyarakat

Pada saat evaluasi, peserta kegiatan pengabdian masyarakat diberikan pertanyaan mengenai jawaban pemakalah atas pertanyaan dari peserta $94 \%$ menjawab bahwa pemakalah memberikan jawaban yang baik dan $6 \%$ peserta menjawab bahwa pemakalah tidak memberikan jawaban yang baik. 


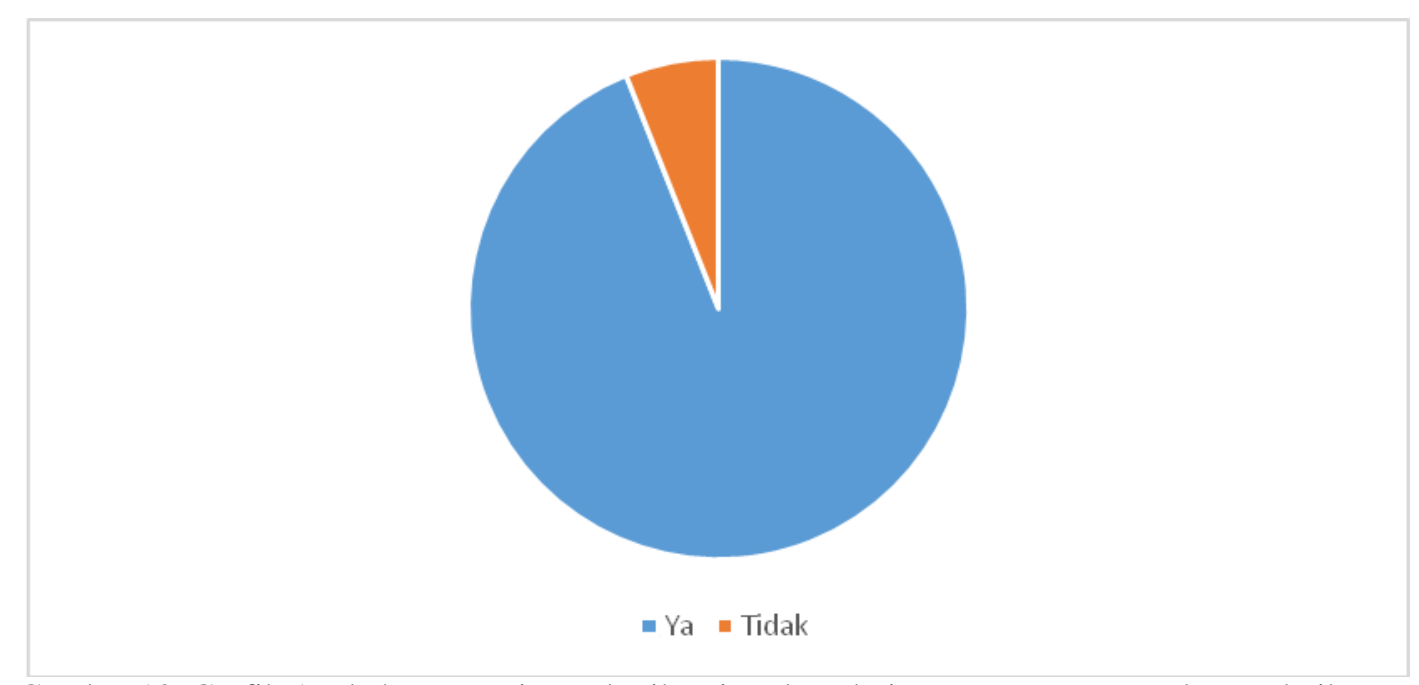

Gambar 10. Grafik Apakah pemateri memberikan jawaban dari pertanyaan peserta dengan baik

Analisis SWOT untuk penelitian dilakukan oleh Wicaksono, A. (2017) menggunakan metode penelitian deskriptif kuantitatif dengan menjelaskan fakta dengan fakta serta data angka dilakukan analisis. [11] Analisis SWOT tipe TSI atau Tanpa Skala Industri dengan analisis EFAS atau analisis faktor eksternal serta IFAS atau analisis faktor internal pada mitra kegiatan. Faktor Internal dari mitra

1. Kekuatan diantaranya,

a. Anggota mitra berusia muda, sehingga motivasi untuk pengembangan diri cukup tinggi

b. mudah menyesuaikan terhadap perkembangan situasi

c. memiliki kemampuan pengoperasian peralatan elektronik

d. memiliki kemampuan dalam mengoperasikan teknologi informasi terutama untuk memperkenalkan produk.

2. Kelemahan diantranya

a. Produk sejenis dipasaran cukup banyak sehingga diperlukan inovasi agar konsumen tertarik.

Faktor Eksternal

1. Peluang diantaranya

a. Pemerintah mendukung pengembangan industri keatif

b. Fasilitas pengembangan diri cukup banyak dan lebih murah serta lebih mudah diakses karena berbasis online

2. Ancaman diantaranya

a. Jumlah pesaing meningkat pada pangsa pasar yang sama, sehingga berdampak kepada ketatnya persaingan pemasaran.

b. Perkembangan lingkungan bisnis yang cepat sehingga diperlukan kecepatan dalam menyesuaikan perkembangan situasi.

Apabila kita analisis alternatif strategi berdasarkan hasil dari SWOT secara umum bila memperhatikan strategi antar situasi dapat kita lihat bahwa untuk Analisa SO yaitu kekuatan dibandingkan kesempatan atau peluang mitra strategi (SO) yang bisa diraih menunjukkan strength (S) dibanding opportunity $(\mathrm{O})$, Kekuatan bisa dioptimalkan berdasarkan peluangnya sehingga dapat digunakan strategi SO menggunakan kekuatan dengan memanfaatkan peluang yang ada, memiliki latar belakang berusia muda dan kemauan untuk berkembang, belajar, kemapuan diri sehingga memiliki kemampuan mencari pangsa pasar yang lebih besar untuk produk yang sudah ada dan pengembangan inovasi produk.

Analisis Strategi WO, menunjukan bahwa opportunity $(\mathrm{O})$ dibanding weakness $(\mathrm{W})$, peluang dalam mengambil manfaat dukungan pemerintah dan akses pengembangan diri, usaha berbasis pemasaran dengan media online sedang tumbuh sehingga pemasaran lebih murah, bisa dibenahi faktor internal, eksternalnya terutama dengan pengembangan diri khususnya penguasaan teknologi dan kemampuan teknologi informasi untuk inovasi pemasaran, penguasaan desain kemasan lebih menarik. Internet telah menjadi salah satu media untuk tujuan pemasaran. Salah satu upaya dalam pemanfaatan media internet adalah untuk proses identitas merek atau sering disebut branding digital.[12]

Analisis Strategi ST, strength $(\mathrm{S})$ dibanding threat $(\mathrm{T})$, kekuatan bisa mengatasi ancaman yang ada dengan menggunakan kekuatan untuk mengatasi ancaman, dengan cara mempertahankan kualitas produk, pengembangan varian produk sehingga konsumen tidak bosen. Analisis Strategi WT, menunjukkan bahwa threat $(\mathrm{T})$ dibanding weakness $(\mathrm{W})$, dengan cara meminimalkan kelemahan untuk menghindari ancaman yang ada. Ancaman yang besar diiringi oleh kelemahan mitra dengan pertambahan pesaing maka mitra harus mampu 
mempertahankan pangsa pasar yang ada dengan mempertahankan kualitas produk, inovasi-inovasi dapat dilakukan untuk menghemat biaya produksi dan pemasaran memanfaatkan perkembangan teknologi informasi sehingga membuka peluang pasar baru.

\section{KESIMPULAN}

Kegiatan pengabdian masyarakat yang diadakan oleh dosen teknik mesin Institut Dirgantara Adisutjipto berkolaborasi dengan UMKM di Propinsi Daerah Istimewa Yogyakarta berjalan cukup baik, hal ini terlihat dari antusiasme peserta yang mengikuti kegiatan ini cukup banyak yaitu 257 peserta. Disamping terlihat dari antusiasme peserta yang cukup banyak juga terlihat dari jawaban peserta untuk mengevaluasi kegiatan pengabdian masyarakat. Dengan adanya analisa SWOT maka mitra diharapkan dapat merencanakan kegiatan bisnisnya dengan lebih baik.

\section{DAFTAR PUSTAKA}

[1] Asih, H. M. dan Fitriani, S. Penyusunan Standard Operating Procedure (SOP) Produk Inovasi Ecobrict, Jurnal Ilmiah Teknik Industri, JITI, Vol. 17 (2), Des 2018,144 - 1 ISSN: 1412-6869 (Print), ISSN: 24604038 (Online) Journal homepage: http://journals.ums.ac.id/index.php/jiti/index, doi: 10.23917/jiti.v17i2.6832. Universitas Muhammadiyah Surakarta.

[2] Sinaga, N., A., "Kode Etik Sebagai Pedoman Pelaksanaan Profesi Hukum Yang Baik", ISSN 2656-4041 (Media Online), Jurnal Ilmiah Hukum Dirgantara-Fakultas Hukum Universitas Dirgantara Marsekal Suryadarma | Volume 10 No. 2, Maret 2020.

[3] Kenedi, J., 2016," Profesi Hukum Dan Kode Etik Profesi”, El-Afkar, Jurnal pemikiran KeIslaman dan Tafsir Hadis Vol. 5 Nomor 1, Januari-Juni 2016. DOI: http://dx.doi.org/10.29300/jpkth.v5i1.1120.

[4] Burhanudin, A., A., Peran Etika Profesi Hukum Sebagai Upaya Penegakan Hukum Yang Baik, Jurnal ElFaqih, Volume 4, Nomor 2, E-ISSN : 2503-314x, P-ISSN : 2443-3950,Tahun 2018.

[5] Wiriantari, F., "Etika Profesi Dan Profesionalisme Bagi Arsitek Dalam Berkarya", Jurnal Anala, Volume 9,No.1, , p-issn: 1907-5286, e-issn: 2722-5682, Tahun 2021.

[6] D. Caesaron, \& Y. Maimury, 2021, "Evaluasi dan Usulan Pengembangan Energi Terbarukan untuk Keberlangsungan Energi Nasional," JIEMS (Journal of Industrial Engineering and Management Systems), vol 7, no. 2, p. 132-139, Maret 2017.

[7] A. H. Subarjo, B. Mardwianta, \& N. Ahmadi, "Peningkatan Pengetahuan Ketahanan Ekonomi Melalui Keterampilan Otomotif Pada Siswa Ibnu Sina," KACANEGARA, Jurnal Pengabdian pada Masyarakat, vol 2, no.1, p. 49-54, Januari 2019.

[8] J. Sitohang, "Penerapan Metode Tanya Jawab Untuk Meningkatkan Hasil Belajar Ipa Pada Siswa Sekolah Dasar," Suara Guru : Jurnal Ilmu Pendidikan Sosial, sains, dan Humaniora Vol. 3 No. 4, P. 681-688, December 2018.

[9] Alma dan Priansa dalam Istiqomah dan Irsad Andriyanto, Analisis SWOT dalam Pengembangan Bisnis (Studi pada Sentra Jenang di Desa Wisata Kaliputu Kudus), Jurnal Bisnis dan Manajemen Islam, Vol. 5, No. 2, Desember 2017.

[10] Solichin, A., Kristanto, D., Triyono, G., "Optimasi pembelajaran daring siswa dan guru di masa pandemi Covid-19 menggunakan Google Classroom pada PKBM Bhakti Asih”, Jurnal Kacanegara, vol. 4, no. 2, p 239-246, Juli 2021.

[11] A. Wicaksono, "Strategi pemasaran dengan menggunakan analisis SWOT tanpa skala industri pada PT X di Jakarta," Jurnal Manajemen industri dan logistik, vol. 1, no. 2, p. 192-201, Nov. 2018.

[12] Kusumaningtyas K., Nugroho, E. D., Priadana, A.,"Penerapan dan pendampingan pengelolaan website sekolah di SMP Negeri 4 Jombang", Jurnal Kacanegara, vol. 4, no. 2, p 195-202, Juli 2021. 